\title{
A note on the chemical composition of low glucosinolate rape seed produced in North-Eastern Poland
}

\author{
S. Matyka ${ }^{1}$, Teresa Jaśkiewicz ${ }^{2}$, Grażyna Bogusz ${ }^{2}$ \\ and W. Korol ${ }^{2}$ \\ ${ }^{1}$ Lublin Agricultural University, Doświadczalna 48, 20-480 Lublin, ${ }^{2}$ Central Laboratory of Feed \\ Industry, Chmielna 2, 20-079 Lublin, Poland
}

(Received 14 May 1992; accepted 1 June 1992)

KEY WORDS: low glucosinolate rape seed, amino acids, fatty acids, minerals, antinutrients INTRODUCTION

Rape seed is the basic raw material of food industry and is a very important crop grown in Poland. The acreage put into rape, which has increased with years, is evidence of that.

The residue after extraction of oil from low glucosinolate (LG) rape seed, LG-rapeseed oil meal, is used for feeding purposes. The chemical composition as well as nutritive value of LG-rapeseed oil meal were determined in many investigations. The good results of breeding to eliminate glucosinolates and erucic acid from rape seed (Krzymański, 1985) have permitted the full fat seed of low glucosinolate varieties to be used also as a feed component for poultry and pigs. Utilization of full fat LG-rape seed of new varieties in animal feeding requires accurate knowledge of its chemical composition. The aim of this paper is to supplement the data on the chemical composition of LG-rape grown in North-Eastern Poland in 1990.

\section{MATERIAL AND METHODS}

Thirty three samples of full fat low glucosinolate rape seed (mainly var. Bolko) were taken from the Feed Mill in Wyszków equipped with a technological line for rape seed cleaning and drying. Each sample represented a lot of rape seed $(5.000 \mathrm{~kg}$ or more) which was used daily in the production of mixed feeds in the feed mill.

Analyses of basic nutrients were performed in all 33 samples. Samples of each 
3 consecutive days were pooled and the 11 samples obtained so were subjected to analysis. Aliquots were taken from these samples and pooled for determination of carotene and xanthophyll. All samples were finely ground before analysis.

Chemical composition was determined using conventional methods. Amino acids were determined in defatted samples on a Beckman Model $119 \mathrm{CL}$ automatic amino acid analyser. Analysis of sulphur amino acid were carried out on samples oxidised before hydrolysis (Moore et al., 1958). Macro- and microelements and toxic metals were determined after ashing the samples using atomic spectrometry (Pye Unicam SP 1900 spectrometer). Phosphorus was determined by the colorimetric molybdate method (Fiske and Subbarow, 1925), molybdenum with the tiocyanate method of Czuba et al. (1970).

The tannin content in defatted samples was estimated by a spectrometric method (Tyczkowska, 1977). Glucosinolates were determined using a semi-quantitative glucose test according to the Polish Standard (1990).

The isothiocyanate level was estimated by gas chromatography (Polish Standard, 1986) and expressed as isobuthylthiocyanate. Fatty acids were analysed by gas chromatography (Siemens, Model L 102) of methyl esters (Matyka, 1976), carotene and xantophyll contents according to Roche (Keller, 1988). The phytate level was assayed by the Oberleas method (1971).

Standard deviations of average values were calculated.

\section{RESULTS AND DISCUSSION}

The chemical and amino acid composition of LG-rape seed are presented in Table 1. The results were similar to those obtained 10 years ago by Kinal and Króliczek (1981) for Polish LG-rape seed varietes, Start, Janpol and Vipol. The investigated LG-rape seed contained higher level of fat and lower level of crude fibre in comparison with Canadian full fat Canola, Candle and Tower seeds (Nwokolo and Sim, 1989; Sibbald, 1986). The amino acid composition of rape seed protein was generally similar to the composition of solvent extracted Canola meal protein (Allen, 1990).

The fatty acid composition of the rape seed (Table 2) confirmed that the analysed seed samples originated from low erucic varieties. The erucic acid content ranged from 0.42 to $2.28 \%$ of total fatty acids. The high levels of polyunsaturated fatty acids, linoleic and linolenic acids, may indicate the high nutritive value of the lipid fraction of the investigated seed. Drozdowski et al. (1990) obtained a similarly low erucic acid content $(0.2-2.0 \%)$ in Polish low glucosinolate rape seed.

The lipid fraction of rape seed also contains compounds which colour poultry carcasses and eggs. The carotene and xanthophyll contents, determined in a pooled representative sample of the analysed material, were 2.1 and 18.4 $\mathrm{mg} / \mathrm{kg}$, respectively. Similar data concerning the xanthophyll content in 
TABLE 1

Chemical and amino acid composition, $\%$ of dry matter

\begin{tabular}{lcc}
\hline \multicolumn{1}{c}{ Indices } & Mean & SD \\
\hline Chemical composition $(\mathrm{n}=33)$ & & \\
Dry matter & 93.7 & 0.80 \\
Crude protein $(\mathrm{N} \times 6.25)$ & 23.3 & 1.08 \\
Crude fat & 44.8 & 1.32 \\
Crude fibre & 7.14 & 0.46 \\
Ash & 4.35 & 0.22 \\
Amino acids $(\mathrm{n}=11)$ & & \\
Aspartic acid & 1.82 & 0.08 \\
Threonine & 1.03 & 0.03 \\
Serine & 1.00 & 0.04 \\
Glutamic acid & 4.39 & 0.31 \\
Glycine & 1.26 & 0.06 \\
Alanine & 1.06 & 0.05 \\
Cystine & 0.61 & 0.04 \\
Valine & 1.04 & 0.14 \\
Methionine & 0.48 & 0.03 \\
Isoleucine & 0.92 & 0.06 \\
Leucine & 1.66 & 0.09 \\
Tyrosine & 0.60 & 0.03 \\
Phenylalanine & 0.91 & 0.05 \\
Lysine & 1.65 & 0.10 \\
Histidine & 0.73 & 0.04 \\
Arginine & 1.54 & 0.08 \\
Tryptophan & 0.25 & 0.02 \\
\hline
\end{tabular}

TABLE 2

Fatty acids content, $\%$ of total fatty acids

\begin{tabular}{lcc}
\hline Acids & Mean & SD \\
\hline C 14:0 - Myristic & 0.09 & 0.02 \\
C 16:0 - Palmitic & 5.58 & 0.24 \\
C 16:1 - Palmitoleic & 0.39 & 0.04 \\
C 17:0 - Margaric & 1.29 & 0.71 \\
C 18:0 - Stearic & 1.89 & 0.19 \\
C 18: 1 - Oleic & 56.9 & 0.63 \\
C 18:2 - Linoleic & 20.3 & 0.82 \\
C 18:3 - Linolenic & 10.4 & 0.52 \\
C 20:1 - Eicosenoic & 1.57 & 0.24 \\
C 22:0 - Behenic & 0.32 & 0.15 \\
C 22:1 - Erucic & 1.01 & 0.66 \\
others & 0.16 & 0.14 \\
\hline
\end{tabular}


TABLE 3

Mineral content (mean of 11 samples) including heavy metals (mean of 22 samples), g or $\mathrm{mg}$ per $\mathrm{kg}$ dry matter

\begin{tabular}{lcc}
\hline Elements & Mean & SD \\
\hline $\mathbf{g}$ & & \\
$\mathrm{Ca}$ & 3.84 & 0.32 \\
$\mathrm{P}$ & 7.83 & 0.81 \\
$\mathrm{Mg}$ & 2.60 & 0.21 \\
$\mathrm{Na}$ & 0.08 & 0.02 \\
$\mathrm{~K}$ & 8.27 & 0.52 \\
\hline $\mathrm{mg}$ & & \\
$\mathrm{Fe}$ & 111.4 & 21.8 \\
$\mathrm{Zn}$ & 54.0 & 7.13 \\
$\mathrm{Mn}$ & 42.5 & 5.89 \\
$\mathrm{Cu}$ & 3.12 & 0.30 \\
$\mathrm{Ni}$ & 1.94 & 0.95 \\
$\mathrm{Co}$ & 0.54 & 0.05 \\
$\mathrm{Mo}$ & 0.75 & 0.12 \\
\hline $\mathrm{mg}$ & & \\
$\mathrm{Pb}$ & & \\
$\mathrm{Cd}$ & 1.36 & 0.22 \\
\hline
\end{tabular}

full-fat Canola seed $(19.2 \mathrm{mg} / \mathrm{kg})$ were reported by Blair and March (1989).

Macro- and microelements as well as the heavy metals content in rape seed are shown in Table 3. A similar mineral content of full fat Canola seed was reported by Nwokolo and Sim (1989). Also data outhe mineral content of solvent extracted Canola meal presented by Allen (1990) were generally similar to ours after recalculating both sets of results on fat free matter.

Lead and cadmium contents in rape seed were higher than in cereal grain (Matyka et al., 1990), still however below the permitted content for these toxic elements in complete feeds - Cd $0.5 \mathrm{mg} / \mathrm{kg}$; Pb $5 \mathrm{mg} / \mathrm{kg}$ (Harenza et al., 1988).

The level of antinutrients (Table 4) - tannin, isothiocyanate and phytate - were rather low and characteristic for low glucosinolate rape seed. The

TABLE 4

The content of antinutritional factors (mean of 11 samples), $\%$ of dry matter

\begin{tabular}{lllll}
\hline \multicolumn{1}{c}{ Antinutrients } & & Value range & Mean & SD \\
\hline Tannin & $0.90-1.33$ & 1.07 & 0.11 \\
Isothiocyanate & $0.0026-0.0498$ & 0.0228 & 0.016 \\
Phytate & $1.54-2.24$ & 1.93 & 0.233 \\
Phytic phosphorus & $0.436-0.635$ & 0.546 & 0.066 \\
\hline
\end{tabular}


glucosinolate content, estimated by the glucose test, was low and did not exceed 25 $\mu \mathrm{mol} / \mathrm{g}$ of defatted matter in all of the investigated samples. A rape seed tannin level in excess of $1 \%$ is indicative of possible diminished protein digestibility. Removal of the hull which accumulates tannin and fibre can be efficient but is an expensive method for improving the nutritive value of LG-rape seed (Żernicki, 1980). The phytate level amounted to $2 \%$. Phytic phosphorus, poorly utilized by young monogastric animals (Matyka et al., 1990a), comprised $69.7 \%$ of the total phosphorus content.

\section{REFERENCES}

Allen R.D., 1990. Ingredient analysis table: 1990 edition. Feedstuffs. Reference Issue. 62 (31), 24-31

Blair R., March B.E., 1989. Canola as a source of xanthophyll for poultry diets. Poultry Sci. 68, 1718-1719 Czuba R., Kamiński W., Strahl A., 1970. Oznaczanie zawartości mikroskładników w materiale roślinnym. Rocz. Glebozn. 21, 135-137

Drozdowski B., Hazuka Z., Tynelc M., 1990. Sklad jakościowy i ilościowy lipidów nasion rzepaku wybranych odmian podwójnie ulepszonych. Zesz. probl. IHAR. Rośliny oleiste cz. I, 191-198

Fiske C.H., Subbarow Y., 1925. The colorimetric determination of phosphorus. J. Biol. Chem., 66, 375-379

Harenza T., Nierodzik A., Matyka S., 1988. Substancje szkodliwe w surowcach i mieszankach paszowych. Zesz, nauk. AR Wroclaw, Wet. XLV, 173, 23-34

Keller H.E., 1988. Analytical methods for vitamins and carotenoids in feed. Hoffman - La Roche, Basel p. 75

Kinal S., Króliczek A., 1981. Sklad chemiczny nasion nowych odmian rzepaku. Zesz. nauk. AR Wroclaw, Zoot. XXIV, 135, 133-141

Krzymański J., 1985. Możliwość podwyższenia zawartości oleju i białka w nasionach rzepaku ozimego w wyniku prac hodowlanych. Biul. Inst. Hod. Akl. Roślin, 157, 3-1 l

Matyka S., 1976. Rutynowa metoda oznaczania zawartości kwasów tłuszczowych. Biul. inf. Przem. Pasz. 15, 38-43

Matyka S., Korol W., Jaśkiewicz T., Bartuzi G., 1990. Tabele składu chemicznego ziarna zbóż. Wydawnictwo wlasne CLPP

Matyka S., Korol W., Bogusz G., 1990. The retention of phytin phosphorus from diets with fat supplements in broiler chicks. Anim. Feed Sci. Technol. 31, 223-230

Moore S., Spackman D.H., Stein W.H., 1958. Chromatography of amino acids on sulfonated polystyrene resins. Anal. Chem. 30, 1185-1190

Nwokolo E., Sim J., 1989. Barley and full-fat Canola seed in broiler diets. Poultry Sci. 68, 1374-1380

Oberleas D., 1971. The determination of phytate and inositol phosphates. Methods Biochem. Anal. 20,87

Polish Standard, 1986. (BN-84) 8054-04. Śruty nasion oleistych: oznaczenia zawartości izotiocyjanianów i 5-winylo-2-oksyzolidynotionu metodą chromatografii gazowej.

Polish Standard 1990. (PN-90) R-66151. Rośliny przemysłowe oleiste . Ziarno rzepaku i rzepiku podwójnie ulepszonego.

Sibbald I. R., 1986. The TME system of feed evaluation: methodology, feed composition data and bibliography. Animal Research Centre Contribution 85-19, Ottawa, Ontario, Agriculture Canada, pp. 114

Tyczkowska K., 1977. Metoda oznaczania kwasu taninowego w ziarnach sorga. Biul. inf. Przem. Pasz. 4, 40-45

Żernicki W., 1980. Wpływ róznych parametrów odłuszczania wybranych surowców paszowych na właściwości fizyczne otrzymanych frakcji. Cz. 1. Badania nad odłuszczaniem ziarna bobiku i rzepaku. Biul. inf. Przem. Pasz. 19, 10-22 


\section{STRESZCZENIE}

Skład chemiczny niskoglukozynolanowych nasion rzepaku, uprawianego w północno-wschodniej części Polski

W 33 próbach nasion rzepaku niskoglukozynolanowego (głównie odm. Bolko), pobranych w Wytwórni Pasz w Wyszkowie, oznaczono zawartość podstawowych składników pokarmowych, w 11 zbiorczych próbach (po 3) - skład aminokwasowy, zawartość makro-i mikroelementów oraz związków antyżywieniowych i kwasów tłuszczowych, w 22 próbach - zawartość ołowiu i kadmu.

Otrzymane dane w większości są zgodne z wynikami innych autorów. 